\title{
Adopting green building constructions in developing countries through capacity building strategy: survey of Enugu State, Nigeria
}

\author{
Daniel Uchenna Chukwu* , Edmund A. Anaele, Hyginus O. Omeje, and Ifeanyi B. Ohanu \\ Department of Industrial Technical Education, University of Nigeria, Nsukka, Nigeria
}

Received: 6 February 2019 / Accepted: 21 October 2019

\begin{abstract}
Green building (GB) constructions seeks to address housing demands of the growing populace with better qualities, energy efficiency, using recycled and recyclable materials, improve building lifespan and health of occupants. But GB adoption lags in developing countries. This study focused on driving the adoption of GB constructions in developing countries through capacity building strategy: survey of Enugu State, Nigeria. Structured questionnaire was used to collect data from 135 building workers in educational and industrial sectors across the registered construction companies and higher institutions in Enugu State. Mean and rank were used to answer the research questions, while $t$-test was used to test five null hypotheses at 0.05 level of significance. Results revealed that there is need for capacity building in: GB design, GB site, GB construction, GB operation and maintenance, and GB construction and demolition waste management. Cluster $t$-test analysis showed discrepancies in the agreement of educational and industrial sector workers on GB design and GB construction needs. The implications for not adopting GB are continual conventional constructions with maximal exploitations and resource depletion. Thus, there is a gap in knowledge where sustainable development advocates, government and pioneers of green construction practices could channel efforts toward assisting the developing countries.
\end{abstract}

Keywords: capacity building / green building construction / conventional construction / building maintenance / construction-demolition wastes

\section{Introduction}

The continuous increase in the world's population has brought the consciousness of not draining the earth's abundant resources in order to meet the future needs. As observed, growth in population causes resultant increase in housing and energy demands, leading to further degradation and depletion of the earth's resources [1]. Mitigating environmental degradation of the building construction industry, reduction in resource consumption through recycling and reusing of materials are vital as the construction industry is responsible for $40 \%$ of all wastes produced [2]. The high percentage of dust, noise, solid waste, smoke and wastewater produced by the construction industry also affect humans [3] causing Sick Building Syndromes (SBS), Building Related Illnesses (BRI) and Multiple Chemical Sensitivity (MCS) from finishes with Volatile Organic Components (VOC) liable for chemical off-gassing [4]. The response of the construction industry to

\footnotetext{
* e-mail: chukwu.daniel@unn.edu.ng
}

the sustainable development agenda demands for ecologically sound land-use policies and energy-efficient designs, increased usage of locally available resources and enhancement of traditional and indigenous building techniques $[5,6]$. Matching-up the housing demand needs of the growing populace in ways that meet sustainable development agenda requires the promotion of efficient technologies and green practices in the building construction industry [3].

Building construction industry in developing countries still engage in conventional constructions majorly associated with brick/block, mortar and concrete as major materials for an end product of a conventional building. Without attention to energy saving, land saving, storm water runoff-reduction, material conservation and pollution reduction [7], conventional buildings oppose green building (GB) constructions [1]. According to EPA cited in Qian et al. [1] green or sustainable building is the practice of creating and using healthier and more resource-efficient models of construction, renovation, operation, maintenance and demolition. GB integrates energy-saving measures such as solar energy cells, sun-shading devices, 
low-emissivity glass, energy-efficient air-conditioning systems, building-space planning and orientation, green roof technology among other design considerations for enhanced sustainable performance [3].

Although the adoptions of GB practices were initially challenged by high costs, literature reports breakthrough and cost benefits in favour of GB over time [8]. For instance, Hoffman and Henn [8] reports that going extra with spacing, finishes and appliances; substituting more polluting to a less polluting product, integrating features or reconfiguring design parameters to take advantage of building system synergies favour operating cost reduction in water, wastewater, and energy expenditures (hard cost benefits) and improved performance of building occupants (soft cost benefits) by 6-26\% [8]. In spite of the many benefits of GB, developing countries lack capacities in both research and skills needed for its adoption [3].

With lack of capacities in green technologies that afford GB constructions, the designing, siting, construction, operation and maintenance as well as management of construction and demolition wastes still follow the conventional method in many developing countries $[9,10]$. The practice of building constructions in developing country of Nigeria including Enugu State negates the global efforts towards sustainable constructions, pays no attention to the many strategies towards GB practices already researched and adopted in most developed countries [3]. Enugu State has massive urban dwellers above the national average [11] and are highly populated resulting to continuous building development on virgin lands without consideration of green practices. Currently, the state is undergoing city decongestion using estate development as strategy. Through this strategy, the state government in one year constructed six massive estates in different locations for high and low level social class [12,13]. There is however no attention of any kind paid towards sustainability in design, site, construction, and material implications. One can imagine what becomes of Enugu State and other Nigerian states in the near future if no measure to adopt sustainable building construction is engaged.

Having noted lack of information, knowledge and awareness, as well as lack of technology and training in green skills [14] as major players amidst other barriers hindering the adoption of GBs, this paper is set to identify capacity building needs for adopting GBs in Nigeria, so as to address areas of skill need in GB design, site, construction, operation and maintenance, and in managing construction and demolition wastes. The study also compared the responses of the building industry sector employees and that of the educational sector in order to ascertain their conformity and divergence with respect to what should constitutes the training in schools and practices required in the world of work to enhance GB adoption. The findings of this study will add to the researches and body of knowledge around GB adoption, especially in developing countries. This study is necessary in calling for assistance and giving direction to the efforts of the developed countries of the world in areas of skill and competency needs for GB adoption. Again, companies and organizations engaging in green technologies will take the findings of this study as a roadmap to design trainings, seminars and workshops targeted for a particular purpose. The remaining part of this paper is structured using the following sub-headings: literature review, methodology, discussion, and lastly, the conclusions.

\section{Literature review}

\subsection{Capacity building needs for GB adoption}

Capacity building needs denote lack of skills, knowledge and necessary drive towards individual or country-based agenda which requires training and necessary exposures for implementation and sustenance of transferred traits. Capacity as the ability of an individual, group, organisation or system to deliver intended outcomes [15]; and capacity building refers to the process of improving, strengthening and maintaining the ability of an entity to perform [16-18]. Previous studies have discovered the problems, barriers and challenges of GB adoption. For instance: Chan et al. [14] identified the barriers to GB adoption to include - resistance of stakeholders to change from the use of traditional technologies; lack of GB technologies databases and information; lack of knowledge and awareness of GB technologies and their benefits; risks and uncertainties involved in implementing new technologies. Many of the challenges facing GB adoption can be resolved to a great extent through capacity building hence there is existing conventional skill base requiring green skills infusion [19]. However, not much research has been conducted to ascertain the areas of needs requiring capacity building. This paper categorized the areas requiring capacity building for GB adoption to include needs for: designing, siting, construction, operation and maintenance, and construction and demolition waste management.

\subsection{GB designing needs}

GBs are cost efficient structures expected to mitigate energy supplies through alternative sustainable generations and utilizations. According to Kibert [4], GB design begins with setting priorities by the owner in collaboration with the project team, selecting the project team - the design team and the construction manager; forming and implementing an integrated design process (IDP), conducting a 'charrette' to obtain input from parties involved, the owner and users, the community, and other stakeholders. Completing the design process follows the path of: schematic design, advanced schematic design, design development, construction documents, and documentation of GB measures using IDP with extensive interdisciplinary interaction to maximize design synergies [4,6]. Riley et al. [6] underscored the importance of integrated design approach used in GB designing as a shift away from linear, sequential design process where building designers, builders and developers will no longer work independently with little interaction and iteration, but in close relationship with others considering comprehensively building systems and features. IDP involves many disciplines and 
creates combination of highly complex data [20,21] which require data management skill from the onset of the design process. Again, GB integrates building simulation analysis which offers virtual reality with respect to: climate, orientation, shadow, solar, energy, acoustics, fire and smoke, fluid dynamics and life cycle assessment (LCA) and life cycle costing (LCC) [20-22]. Effective application of both LCA and LCC can be ensured if the programs are part of architects and engineers' computer aided design (CAD) systems [20] which require mastery. GB designing further requires attention to materials. Plank [23] stated the principal concern for products and materials includes: energy efficiency in manufacture and transportation, reduction in natural resources exploitation, protecting habitats, reducing waste and minimising landfill. In Riley et al. [6] for example, building with straw is appropriate northern plains response to the agenda 21 call on the construction industry to utilize energy-efficient design, increase the input of locally available resources, and enhance traditional and indigenous building techniques. Also, using locally available material is a suitable response to the recommendations to reduce the cost of building materials for low-income citizens and to promote the use of labour-intensive practices to generate employment.

\subsection{GB site needs}

Site here refers to the natural location, orientation and space relationships of GB and other features with respect to building placement. GB site determines the main orientation of the building and possible spacing, the natural day-lighting and the solar access inside the buildings as well as the mutual shading of buildings. Site needs requirements of a GB include: land restorations through reusing, recycling and repairing approaches. Land recycling entails reusing brownfields, grayfields, and blackfields previously impacted by human activities instead of using Greenfield [4]. Reusing developed lands have advantages of reduced automobile dependence, open space conservation, accessible amenities, minimized travel distances and time [24,25]. Furthermore, sustainable sources [26] introduced the 'site repair' strategy which involves choosing a site that has been abused (stripped of vegetation, eroded, and invaded by exotic (non-native) vegetation) for the location of homes. Man-made and natural factors relate in considering where we choose to build and how we build on the site which directly impact the local and global environments, ongoing costs (utility bills, maintenance) [26] and our physical and psychological well-being, which are needful considerations. Equally considered are erosion and sedimentation control which requires detailed planning of systems to minimize soil flows during construction [4].

\subsection{GB construction needs}

GB constructions is the practice of erecting buildings using processes that are environmentally responsible and resource efficient, limiting environmental impact, conserves as much energy and water as possible and are of recycled or renewable materials. Green construction differentiates high-performance GBs from conventional construction practices [4]. In GB construction, specific areas of focus are in site protection planning, improving materials handling, storage and installation, construction and demolition waste management, managing indoor air quality (IAQ) during construction and building commissioning, reusing site materials such as topsoil, lime rock, asphalt, and concrete; metering site electrical and water usage; and reducing pollution generation activities $[27-32,4]$. Thus, at the construction stage of GB, the project manager commonly referred to as 'contractor' [4] ensures that designs are translated into products using best practices. The contractor is expected therefore to have attained expertise hence the absence of required skills calls for capacity building in the demands of green construction.

\subsection{GB operation and maintenance needs}

As buildings are put to use, its continual full operation requires preventive, corrective/reactive, cyclical or scheduled maintenance [33]. The technical meaning of maintenance according to European Federation of National Maintenance Societies [34] and Defence Logistics Agency [35] involves operational and functional checks, servicing, repairing or replacing of necessary devices, equipment, machinery, building infrastructure and supporting utilities in business, governmental and residential installations. Chanter and Swallow [36] stated that operation and maintenance enable the building to continue to efficiently perform according to design. Proper GB operation and maintenance ensures reduced energy consumption for new productions and improved product quality with prolonged life span [36-38]. Maintenance decreases greenhouse gas emissions, saves cost on energy and preserves the environment [39].

However, sustainable operations and maintenance (O\&M) practices focus primarily on actions of building occupants, and encompass health and safety, comfort and productivity, reusing and recycling building components [28]. As such training is needed for building occupants, facilities managers, and maintenance staff in: sustainable design principles and methods that will minimize system failures; ensure use of cleaning products and supplies that are resource-efficient, bio-degradable and safe for both janitorial staff and building occupants, thereby promoting good indoor air quality $[28,37]$. Other important operation and maintenance steps require: regular check on sensor control points to ensure energy efficiency is not compromised, use of automated monitors and controls for energy, water, waste, temperature, moisture, and ventilation; reducing waste through source reduction, reuse, recycling and/or composting to eliminate disposal of reusable materials at landfills and incinerators; minimizing travel by supporting telecommuting programs and enabling a mobile work environment, performing scheduled energy audits and re-commissioning of systems; and choosing higher efficiency equipment and durable materials that will withstand storms and other natural events, and improve the tightness of the building envelope $[28,37,4]$. 


\subsection{GB construction and demolition wastes management needs}

The entire building construction stages are characterized by waste generation - from the extraction of the raw materials to the manufacturing of materials, the construction process proper, its demolition and finally the disposal of the waste materials in landfills [40]. Construction and demolition waste (CDW) refers to mixture of materials or debris generated as a result of construction, refurbishment, deconstruction or demolition of structures and buildings [40]. In GB, deconstruction is favoured against demolition. Demolition is a complete destruction of an existing building, structure or space, leading to the creation of mixed waste, while deconstruction is a reversed construction where the building elements are dismantled for the purpose of reusing or enhancing recycling [4]. CDW are classified into: masonry wastes of concrete, bricks, tiles and ceramics; wood, glass and plastic; bituminous mixtures, tar macadam and other tar products; metals (including their alloys); soil (including that which is excavated from contaminated areas); stones and dredged soil; insulation materials and construction materials containing asbestos; gypsum-based materials; mixed construction and demolition materials [40,41]. Construction wastes arise from poor businesses and waste reduction in construction is an assured way of paying for sustainability [42]. To improve waste management on building site, Merino et al. [40] suggests reduced onsite source and allocating waste management strategy responsibilities to all actors on site. Kibert [4] suggests, CDW management requires: reduced onsite fabrication with offsite production of exact quantity needed, using buy-back strategy for unused materials; onsite synergy of purpose among contractors and subcontractors to avoid reworking; conducting material auditing before deconstruction; using designated areas for storage, fabrication etc; as well as using concrete, bricks and concrete masonry units (CMU) for sub base in construction. CDW if properly managed creates savings that further cushion the initial capital investment required for GB projects [42].

\section{Methodology}

\subsection{Data collection}

Questionnaire was used as a recognized survey research instrument that sought opinions [43] of building industry workers, lecturers and teachers on the capacity building needs towards adopting sustainable constructions. Building industry workers, lecturers and teachers here refer to those who have passed through building related courses such as building construction, building technology, civil engineering, architecture, plumbing and pipe fittings among others in secondary, college and university levels to become an employer or employee in either the building industry or in the educational sector, and are thus categorized into two groups. Group one consists of lecturers and teachers, referred to as the 'educational sector employees' while building experts and site workers called 'industrial sector employees' were in group two. The questionnaire titled Green Building Capacity Building Needs (GBCBN) was defined based on the five clusters that constitute the objectives of the study. The questionnaire had 77 items sectioned A-F, where Section A consists of demographic information, Section B consists of 20 items on GB design needs, section $\mathrm{C}-15$ items on GB site needs, section D - 17 items on GB construction needs, section $\mathrm{E}-$ 14 items on GB operation and maintenance needs, and section F - 11 items on GB construction and demolition wastes management needs. The instrument was designed based on five point Likert scale rating of Highly Needed $(\mathrm{HN})$, Slightly Needed (SN), Neutral (N), Slightly Not Needed (SNN) and Highly Not Needed (HNN) with assigned weights of $5,4,3,2$, and 1 respectively.

Before the instrument was administered, three building professionals were given the questionnaire, two in educational sector and one from the industry. The professionals were requested to assess the appropriateness of the instrument in line with intended objectives, and to suggest addition, removal or recast of the questionnaire items. Their suggestions improved the outcome of the instrument; for instance, they suggested that the cluster containing 'operation and maintenance needs' and 'construction and demolition management needs' be divided to highlight the differences, as it is in the final instrument used. Also prior to distribution of the questionnaire, Cronbach's alpha coefficient was used to evaluate the reliability of the items of the instrument based on the five-point rating scale. Cronbach's alpha coefficient value of .93 was obtained indicating a high internal consistency of the instrument, and therefore was distributed.

Copies of the questionnaire were distributed to building industry experts and site workers, lecturer and teachers across Enugu State of Nigeria. A total of 158 copies of the questionnaire were administered but 135 were retrieved representing 85 percent return rate, and were used for the data analysis.

\subsection{Data analysis}

To obtain mean, rank and the significant differences among respondents in this study, the respondents were grouped into two as in the demographic variable of employment sector: educational and industrial. In line with Darko et al. [44] and related studies, mean value analysis was used to determine the need for capacity building in areas of knowledge inadequacy as indicated by the respondents. Ranking was used for variable comparison. Variable comparison is necessary to direct efforts on the capacity building from the highly needed to the not needed responses of the two groups. Furthermore, $t$-test was used to compare the significant differences in the groups' responses at 0.05 level of significance and mean value of 3.5 and above.

\section{Discussion}

The overview of the responses of lecturers, instructors, teachers and technologists in group 1, building industry site workers with minimum of senior secondary certificate 
Table 1. Mean, rank, $t$-test and significance of the respondents on GB design needs.

\begin{tabular}{|c|c|c|c|c|c|c|c|c|c|}
\hline \multirow[t]{2}{*}{$\mathrm{S} / \mathrm{n}$} & \multirow[t]{2}{*}{ Items } & \multicolumn{2}{|c|}{ Total sample } & \multicolumn{2}{|c|}{ Group 1} & \multicolumn{2}{|c|}{ Group 2} & \multirow[t]{2}{*}{$t$-cal } & \multirow[t]{2}{*}{ Sig. } \\
\hline & & Mean & Rank & Mean & Rank & Mean & Rank & & \\
\hline 1 & Good knowledge of GB through expert classes and trainings & 4.53 & 1 & 4.67 & 1 & 4.45 & 1 & 2.10 & 0.04 \\
\hline 2 & Setting priorities of interest among GB goals & 4.11 & $11^{\mathrm{a}}$ & 4.04 & 8 & 4.15 & 16 & -0.70 & 0.49 \\
\hline 3 & $\begin{array}{l}\text { Sourcing energy saving-systems such as } \\
\text { energy-efficient heating, ventilation } \\
\text { and air conditioning (HVAC) } \\
\text { for inclusion in design }\end{array}$ & 4.11 & $11^{\mathrm{a}}$ & 3.89 & 13 & 4.22 & 10 & -2.02 & 0.05 \\
\hline 4 & $\begin{array}{l}\text { Integrating enhanced solar-sensitive } \\
\text { devices such as low-emissivity glass, } \\
\text { sun-shading devices }\end{array}$ & 4.08 & $15^{\mathrm{a}}$ & 3.87 & $15^{\mathrm{a}}$ & 4.19 & 11 & -1.84 & 0.07 \\
\hline 5 & Assembling integrated design team & 4.04 & 17 & 3.89 & 13 & 4.11 & 17 & -1.14 & 0.26 \\
\hline 6 & $\begin{array}{l}\text { Playing active role in articulating the } \\
\text { design using integrated design process }\end{array}$ & 4.22 & 4 & 4.07 & $6^{\mathrm{a}}$ & 4.30 & $5^{\mathrm{a}}$ & -1.70 & 0.09 \\
\hline 7 & Read and interpret schematic designs & 4.20 & $6^{\mathrm{a}}$ & 4.41 & 2 & 4.09 & 18 & 1.74 & 0.08 \\
\hline 8 & Prepare detailed construction documents & 4.28 & 2 & 4.17 & 4 & 4.34 & $3^{\mathrm{a}}$ & -1.29 & 0.20 \\
\hline 9 & $\begin{array}{l}\text { Document GB measures required } \\
\text { for building certification }\end{array}$ & 4.12 & 10 & 3.89 & 13 & 4.24 & 8 & -2.10 & 0.04 \\
\hline 10 & Formulating initial budget of construction & 4.09 & 14 & 3.80 & 18 & 4.24 & 8 & -2.23 & 0.03 \\
\hline 11 & Scheduling for purchases/procurement & 4.00 & 18 & 3.70 & $19^{\mathrm{a}}$ & 4.16 & 15 & -2.66 & 0.01 \\
\hline 12 & Using collaborative software for building analysis & 4.20 & $6^{\mathrm{a}}$ & 4.24 & 3 & 4.18 & 12 & 0.36 & 0.72 \\
\hline 13 & $\begin{array}{l}\text { Initiating relational contracts or collaborative } \\
\text { agreement with clarity of purposes }\end{array}$ & 4.16 & 9 & 3.87 & $15^{\mathrm{a}}$ & 4.30 & $5^{\mathrm{a}}$ & -2.75 & 0.01 \\
\hline 14 & $\begin{array}{l}\text { Integrating Building Information Modelling (BIM) and } \\
\text { energy simulations in design and performance analysis }\end{array}$ & 4.18 & 8 & 4.07 & $6^{\mathrm{a}}$ & 4.24 & 8 & -0.98 & 0.33 \\
\hline 15 & Applying technology towards GB development & 4.26 & 3 & 4.11 & 5 & 4.34 & $3^{\mathrm{a}}$ & -1.45 & 0.15 \\
\hline 16 & Initiating and ensuring proper communication links & 4.08 & $15^{\mathrm{a}}$ & 3.91 & 11 & 4.17 & $13^{\mathrm{a}}$ & -1.42 & 0.16 \\
\hline 17 & Familiarity with assessment systems and requirements & 3.92 & 20 & 3.70 & $19^{\mathrm{a}}$ & 4.03 & 20 & -1.80 & 0.07 \\
\hline 18 & $\begin{array}{l}\text { Using Life Cycle Costing (LCC) and Life Cycle } \\
\text { Analysis (LCA) in selecting features }\end{array}$ & 3.98 & 19 & 3.85 & 17 & 4.04 & 19 & -1.07 & 0.29 \\
\hline 19 & Reconfiguring design patterns to suit environment & 4.10 & 13 & 3.96 & 9 & 4.17 & $13^{\mathrm{a}}$ & -1.22 & 0.23 \\
\hline 20 & Factoring workers motivational incentives in budget & 4.21 & 5 & 3.93 & 10 & 4.36 & 2 & -2.47 & 0.01 \\
\hline & Cluster value & 4.14 & & 4.00 & & 4.21 & & -2.64 & 0.01 \\
\hline
\end{tabular}

Note: Group 1 refers to lecturers, instructors, teachers and technologists teaching building construction and related trades in tertiary and secondary institutions. Group 2 refers to building industry workers such as engineers, architects, technicians, plumbers, etc with minimum of Senior Secondary certificate in building related trades. ${ }^{\mathrm{a}}=$ Equal ranks wherein the next rank is skipped; $\mathrm{t}$-cal $=$ Calculated $t$-value; Sig. = Level of significance at 0.05 .

in group 2 and the overall or total sample responses are presented in Tables $1-5$. The tables show mean values, ranks, $t$-cal and significance. Figures $1-5$ also show visuals of the groups' responses. Discussions are made based on the total sample responses and on the group responses using the areas of needs.

\subsection{GB design needs}

The result in Table 1 shows a list of GB design needs identified to be highly needed by the respondents, with mean and ranked order. There is general acceptance of the 20-GB design items as the cluster mean value shows 4.14. It could be deduced that the lack of GB in Nigeria is as a result of inadequate competencies thus requiring capacity building in GB design as validated by the findings of Okafor [10] and Ogunsote et al. [9]. From the results, 'good knowledge of GB through expert classes and trainings' ranked first with mean value of 4.53 [45]; the second is 'preparing detailed GB construction documents', mean value of 4.28; third 'applying technology towards GB' with mean of 4.26 ; 'playing active role in articulating design using integrated design process', ranked fourth having mean of 4.22 ; while 'factoring workers motivational incentives in budget', fifth position with mean of 4.21. However, the least ranked GB design need, 'familiarity with assessment systems and requirements,' does not imply unimportance but could be a function of lack of knowledge in GB. This is because lack of knowledge in GB, according to Jasimin and Ali [46] and Deniz [47], has been a major hindrance in the adoption of GB in most countries. Lack of knowledge is equally a factor hindering GB research and communication in such countries [3]. Also, the $t$-test analysis in Table 1 shows that 14 out of the 
Table 2. Mean, rank, $t$-test and significance of the respondents on GB site needs.

\begin{tabular}{|c|c|c|c|c|c|c|c|c|c|}
\hline \multirow[t]{2}{*}{$\mathrm{S} / \mathrm{n}$} & \multirow[t]{2}{*}{ Items } & \multicolumn{2}{|c|}{ Total sample } & \multicolumn{2}{|c|}{ Group 1} & \multicolumn{2}{|c|}{ Group 2} & \multirow[t]{2}{*}{$t$-cal } & \multirow[t]{2}{*}{ Sig. } \\
\hline & & Mean & Rank & Mean & Rank & Mean & Rank & & \\
\hline 21 & Site assessment for contaminants & 4.32 & 1 & 4.43 & 1 & 4.26 & $2^{\mathrm{a}}$ & 1.19 & 0.24 \\
\hline 22 & $\begin{array}{l}\text { Land recycling and redevelopment including } \\
\text { brownfields, grayfield and blackfield }\end{array}$ & 4.07 & 7 & 3.96 & 7 & 4.13 & 7 & -1.06 & 0.29 \\
\hline 23 & Site repair and restoration & 4.04 & $8^{\mathrm{a}}$ & 4.13 & 4 & 4.00 & 11 & 0.74 & 0.46 \\
\hline 24 & Best green site practices e.g. avoiding compaction & 3.73 & 15 & 3.46 & 15 & 3.87 & 14 & -1.73 & 0.09 \\
\hline 25 & Restricting construction vehicle traffic driveways/accesses & 3.90 & 13 & 3.74 & 12 & 3.99 & $12^{\mathrm{a}}$ & -1.30 & 0.19 \\
\hline 26 & Integrating landscape areas against parking spaces & 3.95 & 11 & 3.70 & 13 & 4.08 & $9^{\mathrm{a}}$ & -2.12 & 0.04 \\
\hline 27 & $\begin{array}{l}\text { Leveraging on natural environment in landscaping for } \\
\text { controlled heating and cooling }\end{array}$ & 4.13 & 4 & 3.91 & 9 & 4.24 & 4 & -2.22 & 0.03 \\
\hline 28 & $\begin{array}{l}\text { Orientating buildings for efficiency of the } \\
\text { desired outcome (cold or heat) }\end{array}$ & 4.19 & 3 & 4.22 & 2 & 4.18 & $5^{\mathrm{a}}$ & 0.23 & 0.82 \\
\hline 29 & Site stormwater management & 4.02 & 10 & 3.87 & 10 & 4.10 & 8 & -1.26 & 0.21 \\
\hline 30 & $\begin{array}{l}\text { Reusing and upgrading of old sites and } \\
\text { buildings over greenfields }\end{array}$ & 3.91 & 12 & 4.11 & 5 & 3.81 & 15 & 1.39 & 0.17 \\
\hline 31 & Reducing car dependence or sprawl to minimize pollution & 4.04 & $8^{\mathrm{a}}$ & 3.98 & 6 & 4.08 & $9^{\mathrm{a}}$ & -0.55 & 0.58 \\
\hline 32 & Creating an accessible pedestrian walk and bicycle paths & 4.29 & 2 & 4.15 & 3 & 4.36 & 1 & -1.33 & 0.19 \\
\hline 33 & Topography management & 4.10 & $5^{\mathrm{a}}$ & 3.78 & 11 & 4.26 & $2^{\mathrm{a}}$ & -2.82 & 0.01 \\
\hline 34 & Hydrology management & 3.83 & 14 & 3.52 & 14 & 3.99 & $12^{\mathrm{a}}$ & -2.26 & 0.03 \\
\hline \multirow[t]{2}{*}{35} & Designating staging areas for materials & 4.10 & $5^{\mathrm{a}}$ & 3.93 & 8 & 4.18 & $5^{\mathrm{a}}$ & -1.33 & 0.18 \\
\hline & Cluster value & 4.04 & & 3.93 & & 4.10 & & -1.92 & 0.06 \\
\hline
\end{tabular}

Note: Group 1 refers to lecturers, instructors, teachers and technologists teaching building construction and related trades in tertiary and secondary institutions. Group 2 refers to building industry workers such as engineers, architects, technicians, plumbers, etc with minimum of Senior Secondary certificate in building related trades. ${ }^{\mathrm{a}}=$ Equal ranks wherein the next rank is skipped; $\mathrm{t}$-cal $=$ Calculated $t$-value; Sig. $=$ Level of significance at 0.05 .

20 items on GB design needs are not significant while 6 are significant. The cluster $t$-value, 0.01 is significant, confirming the discrepancies in the agreement between educational sector workers and building industry workers over GB design needs. Hence, the hypothesis of no significant difference on GB design needs between educational sector and industrial sector workers was rejected.

This finding is in line with the report of Spork [48] that there is mismatch between the theory in school and practice in the world of work. There is need for educational sectors and building industry giants to align in GB pursuits through capacity building. Efficiently delivered capacity building on GB design would force the schools to reposition theory and practical toward GB actualization and equally position the industry to receive and engage the students in profitable ventures after graduation.

\subsection{GB site needs}

From the total sample responses in Table 2, item 21 'site assessment for contaminants' appears to be the capacity highly needed in GB sites. It is very vital to site GB on contaminated lands [49] hence Kibert [4] reports that GB favours already developed lands over green fields. The respondents understand the importance of assessing brownfields, grayfields and blackfields for underutilization

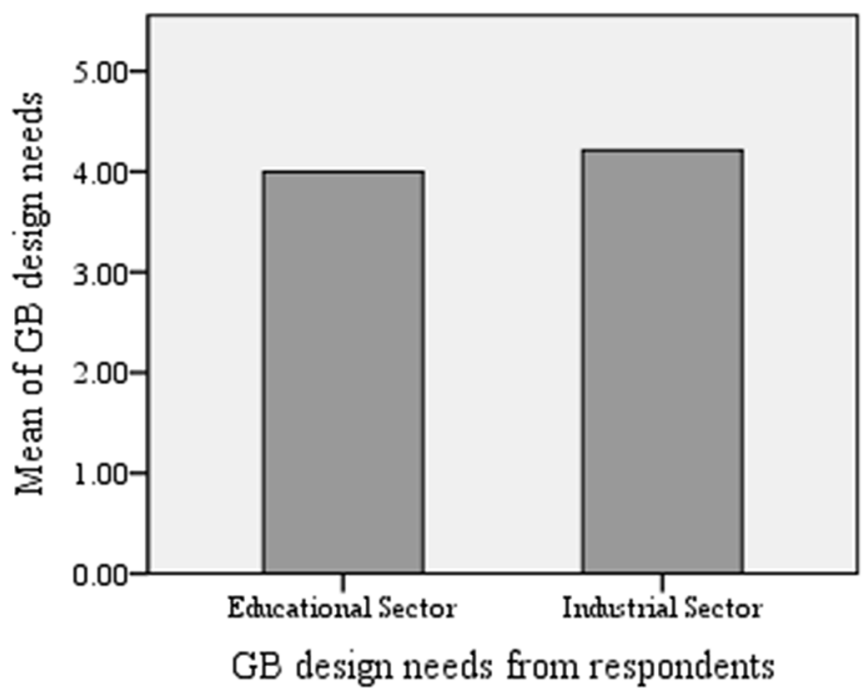

Fig. 1. GB design capacity building needs.

and subsequent upgrade, redevelopment, recovery, restoration and recycling (items 22, 23 and 30) thereby reducing the invasion of virgin lands. Ranked second in table 2 is 'creating an accessible pedestrian walk and bicycle paths' with mean value of 4.15 , which is in line with 'reducing car dependence or sprawl to minimize pollution' and 'restricting vehicle traffic' (items 31 and 25). Supporting this 
Table 3. Mean, rank, $t$-test and significance of the respondents on GB construction needs.

\begin{tabular}{|c|c|c|c|c|c|c|c|c|c|}
\hline \multirow[t]{2}{*}{$\mathrm{S} / \mathrm{n}$} & \multirow[t]{2}{*}{ Items } & \multicolumn{2}{|c|}{ Total sample } & \multicolumn{2}{|c|}{ Group 1} & \multicolumn{2}{|c|}{ Group 2} & \multirow[t]{2}{*}{$t$-cal } & \multirow[t]{2}{*}{ Sig. } \\
\hline & & Mean & Rank & Mean & Rank & Mean & Rank & & \\
\hline 36 & Reducing building site pollution & 4.43 & 2 & 4.33 & 3 & 4.48 & 1 & -1.13 & 0.26 \\
\hline 37 & Shedding top-soil and avoiding top soil run-off & 4.18 & 8 & 4.00 & $9^{\mathrm{a}}$ & 4.27 & $6^{\mathrm{a}}$ & -1.87 & 0.06 \\
\hline 38 & Minimizing impact of light pollution & 4.28 & 5 & 3.93 & 12 & 4.46 & $2^{\mathrm{a}}$ & -3.91 & 0.00 \\
\hline 39 & Avoiding site disturbances to minimize degradation & 4.12 & 11 & 3.83 & 14 & 4.27 & $6^{\mathrm{a}}$ & -2.93 & 0.00 \\
\hline 40 & Site erosion control & 4.30 & $3^{\mathrm{a}}$ & 4.15 & 6 & 4.37 & 4 & -1.37 & 0.17 \\
\hline 41 & Sedimentation control & 3.99 & 15 & 3.78 & 15 & 4.09 & 14 & -1.80 & 0.07 \\
\hline 42 & On-site manufacturing techniques & 4.10 & 12 & 4.09 & 8 & 4.11 & 13 & -0.15 & 0.88 \\
\hline 43 & Improving material handling & 4.19 & 7 & 4.15 & 6 & 4.20 & $8^{\mathrm{a}}$ & -0.31 & 0.76 \\
\hline 44 & Effective procurement as at when needed & 4.23 & 6 & 4.35 & 2 & 4.17 & 11 & 1.22 & 0.22 \\
\hline 45 & Efficient storage as pertains to materials and products & 4.30 & $3^{\mathrm{a}}$ & 4.28 & 4 & 4.30 & 5 & -0.14 & 0.89 \\
\hline 46 & Accurate installations of materials and products & 4.46 & 1 & 4.46 & 1 & 4.46 & $2^{\mathrm{a}}$ & -0.04 & 0.97 \\
\hline 47 & Managing Indoor Air Quality (IAQ) & 4.13 & 10 & 4.00 & $9^{\mathrm{a}}$ & 4.20 & $8^{\mathrm{a}}$ & -1.31 & 0.19 \\
\hline 48 & Reusing onsite generated topsoil in landscaping & 3.85 & 17 & 3.72 & 16 & 3.92 & 17 & -1.07 & 0.29 \\
\hline 49 & Metering site electrical and water usage & 4.04 & $13^{\mathrm{a}}$ & 3.98 & 11 & 4.07 & 15 & -0.52 & 0.60 \\
\hline 50 & Communicating site goals with sanctions for defaulters & 4.04 & $13^{\mathrm{a}}$ & 3.87 & 13 & 4.12 & 12 & -1.67 & 0.10 \\
\hline 51 & Sourcing reclaimed materials for site equipment & 3.87 & 16 & 3.63 & 17 & 4.00 & 16 & -1.92 & 0.06 \\
\hline \multirow[t]{2}{*}{52} & $\begin{array}{l}\text { Conducting safety meetings for goal } \\
\text { assessment and alignment }\end{array}$ & 4.17 & 9 & 4.15 & 6 & 4.18 & 10 & -0.17 & 0.87 \\
\hline & Cluster value & 4.16 & & 4.04 & & 4.22 & & -2.29 & 0.02 \\
\hline
\end{tabular}

Note: Group 1 refers to lecturers, instructors, teachers and technologists teaching building construction and related trades in tertiary and secondary institutions. Group 2 refers to building industry workers such as engineers, architects, technicians, plumbers, etc with minimum of Senior Secondary certificate in building related trades. ${ }^{a}=$ Equal ranks wherein the next rank is skipped; $t$-cal $=$ Calculated $t$-value; Sig. = Level of significance at 0.05 .

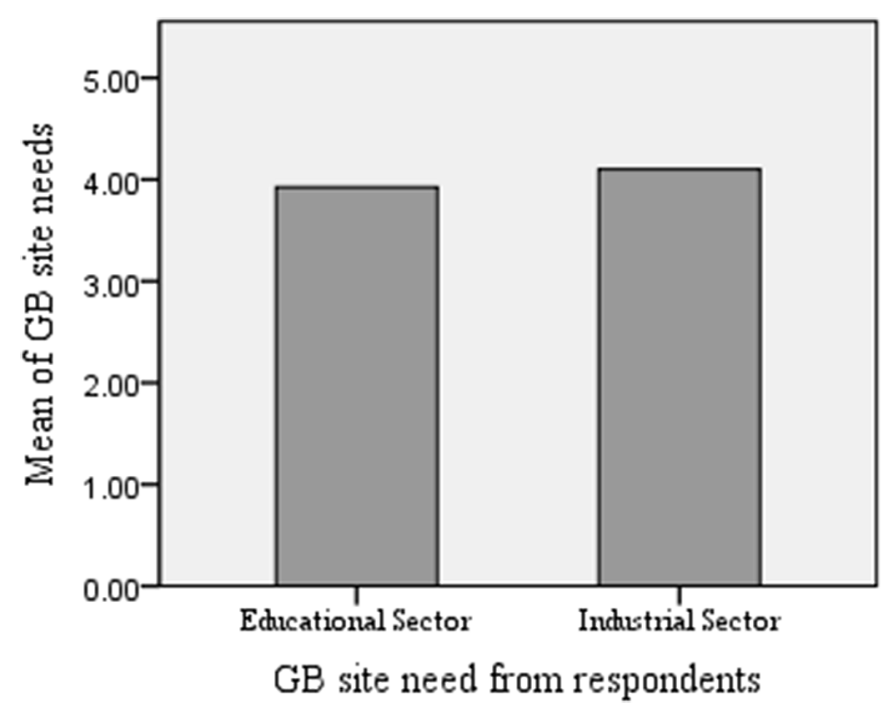

Fig. 2. GB site capacity building needs.

finding is the report of Newman and Kenworthy [50], who stated that reduction in car dependence using various strategies is a necessity for sustainable environment. Therefore, GB is often sited amidst developed amenities, functional mass transits, with nearness to school, work and shopping centres are desirable site goals [4,23]. Achieving site goals also require capacities to orientate buildings for efficiency of heating and cooling (item 28, ranked third) and 'leveraging on natural environment in landscaping for controlled heating and cooling' (item 27, ranked fourth). Heating and cooling is the major energy consuming channel in a building [22], thus the respondents agree that capacity to leverage on nature is a worthwhile skill needed to cut energy cost in daily basis irrespective of season and location. According to the study by Alhajeri [51], energy saving through the use of renewable sources is one major goal of every known GB and requires that people be trained to analyze, monitor and report energy consumptions for improvement.

Table 2 further shows the $t$-test analysis to compare responses from industrial and educational sectors. It shows that four items $(26,27,33$ and 34$)$ are significant while the remaining ten items turn-out not significant at 0.05 level of significance. The cluster $t$-value however reinstates a not significant result having 0.06 ; therefore, the hypothesis of no significant difference in the mean responses of the two groups was not rejected.

It is further observed from the table that while 'hydrology management' and 'topography management' matter more to building industry experts, it matters little to the educational sector counterparts. This observation is in consonance with the findings of Darko et al. [44] who stated that water efficiency in GB can lower lifetime bill and enhance economic costs, which only those with real construction experiences attest. 
Table 4. Mean, rank, $t$-test and significance of the respondents on GB operation and maintenance needs.

\begin{tabular}{|c|c|c|c|c|c|c|c|c|c|}
\hline \multirow[t]{2}{*}{$\mathrm{S} / \mathrm{n}$} & \multirow[t]{2}{*}{ Items } & \multicolumn{2}{|c|}{ Total sample } & \multicolumn{2}{|c|}{ Group 1} & \multicolumn{2}{|c|}{ Group 2} & \multirow[t]{2}{*}{$t$-cal } & \multirow[t]{2}{*}{ Sig. } \\
\hline & & Mean & Rank & Mean & Rank & Mean & Rank & & \\
\hline & Operating GB requires & & & & & & & & \\
\hline 53 & Proper documentation of installations and input details & 4.47 & 1 & 4.63 & 1 & 4.39 & 1 & 2.13 & 0.03 \\
\hline 54 & Establishing commissioning or certification criteria of a project & 4.26 & 5 & 4.11 & 6 & 4.34 & $2^{\mathrm{a}}$ & -1.54 & 0.13 \\
\hline 55 & Providing operational and maintenance manual of buildings & 4.29 & 3 & 4.22 & 4 & 4.33 & 4 & -0.76 & 0.45 \\
\hline 56 & Using automated monitors for energy and water consumption & 3.99 & 12 & 3.85 & 13 & 4.07 & 12 & -1.19 & 0.24 \\
\hline 57 & Determining material life cycle & 4.21 & 6 & 4.07 & 7 & 4.28 & 6 & -1.45 & 0.15 \\
\hline 58 & Integrating composting to eliminate disposals & 3.91 & $13^{\mathrm{a}}$ & 3.83 & 14 & 3.96 & 13 & -0.71 & 0.48 \\
\hline 59 & $\begin{array}{l}\text { Training building occupants and stakeholders on } \\
\text { operation and maintenance of features } \\
\text { Maintaining GB requires }\end{array}$ & 4.32 & 2 & 4.28 & 3 & 4.34 & $2^{\mathrm{a}}$ & -0.37 & 0.71 \\
\hline 60 & Estimating schedules for repairs or replacement & 4.27 & 4 & 4.17 & 5 & 4.31 & 5 & -1.01 & 0.31 \\
\hline 61 & Evaluating components' routine/reactive maintenance & 4.06 & 11 & 3.96 & $11^{\mathrm{a}}$ & 4.11 & 11 & -0.98 & 0.33 \\
\hline 62 & Using non-toxic compounds in cleaning & 3.91 & $13^{\mathrm{a}}$ & 3.96 & $11^{\mathrm{a}}$ & 3.89 & 14 & 0.35 & 0.73 \\
\hline 63 & $\begin{array}{l}\text { Avoiding chemicals or materials with volatile } \\
\text { organic compounds (VOCs) }\end{array}$ & 4.19 & 7 & 4.30 & 2 & 4.13 & 10 & 0.97 & 0.33 \\
\hline 64 & $\begin{array}{l}\text { Energy auditing of equipment and products } \\
\text { before reinstallations }\end{array}$ & 4.10 & 10 & 4.00 & 9 & 4.16 & 9 & -1.03 & 0.30 \\
\hline 65 & Selecting higher efficiency products during updates & 4.14 & $8^{\mathrm{a}}$ & 3.98 & 10 & 4.22 & 7 & -1.65 & 0.10 \\
\hline \multirow[t]{2}{*}{66} & Updating structures with more durable systems & 4.14 & $8^{\mathrm{a}}$ & 4.04 & 8 & 4.19 & 8 & -0.95 & 0.34 \\
\hline & Cluster value & 4.16 & & 4.10 & & 4.19 & & -1.13 & 0.26 \\
\hline
\end{tabular}

Note: Group 1 refers to lecturers, instructors, teachers and technologists teaching building construction and related trades in tertiary and secondary institutions. Group 2 refers to building industry workers such as engineers, architects, technicians, plumbers, etc with minimum of Senior Secondary certificate in building related trades. ${ }^{\mathrm{a}}=$ Equal ranks wherein the next rank is skipped; $t$-cal $=$ Calculated $t$-value; Sig. $=$ Level of significance at 0.05 .

According to Kibert [4], negligence has always played out in matters of building site, as it is fully left in the purview of the owner, but GB development uses integrated project team of experts where skills are utilized to achieve the best a site can offer or to redevelop or optimize poor performing sites. Nigeria and other developing countries need capacity building to take advantage of underdeveloped building sites.

\subsection{GB construction needs}

The 17 items on GB construction needs listed in Table 3 had mean values ranging from 3.85-4.46, 3.63-4.46, and 3.92-4.48 for the total sample, group 1 and group 2 respectively. It indicates that the building trades experts in educational sector and building industry need capacity building in constructing GBs. Table 3 reveals that item 46 'accurate installations of materials and products' was ranked first, in the total sample and group 1 analysis whereas group 2 ranked same item second. Indicating that the most important GB construction capacity needed according to the respondents is accurate installation of materials and products. This finding is validated by the studies conducted by Hasan and Zhang [52], Rahimian et al. [53], and Hwang and Tan [54], who observed variant technicalities needed in the GB constructions, such that accuracy in installing both offsite and onsite manufactured materials is necessary in mitigating wastes. In support,

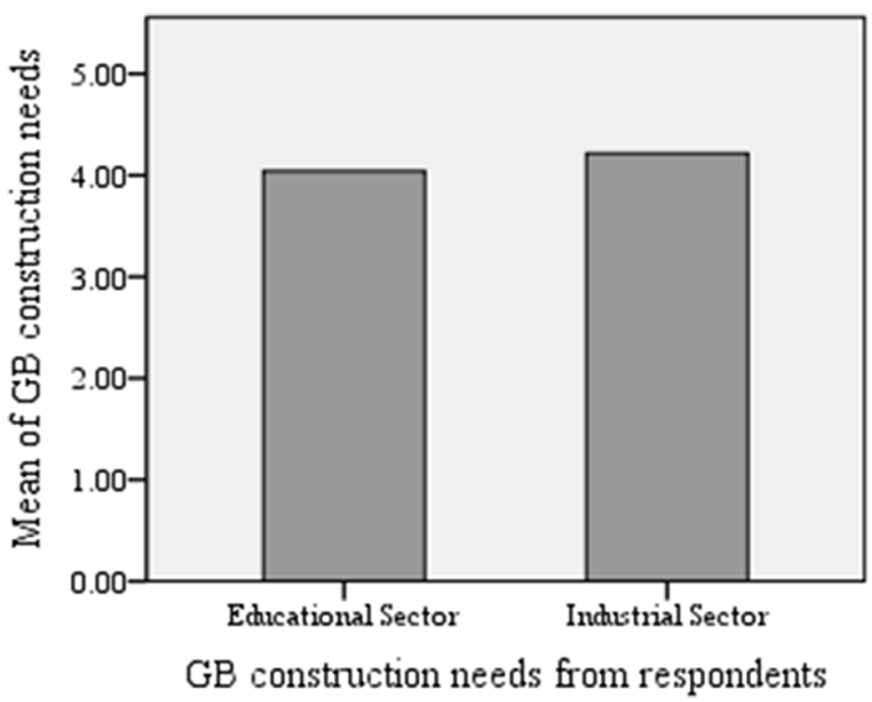

Fig. 3. GB construction capacity building needs.

$\mathrm{Du}$ Plessis [26] affirms that there is need for careful handling, storage and installation of materials in GB constructions. Also, Item 36 'reducing building site pollution' is ranked second in total sample, third in group 1 and first in group 2. Literature records that capacity to reduce building site pollution is important in meeting the 
Table 5. Mean, rank, $t$-test and significance of the respondents on GB construction and demolition waste management needs.

\begin{tabular}{|c|c|c|c|c|c|c|c|c|c|}
\hline \multirow[t]{2}{*}{$\mathrm{S} / \mathrm{n}$} & \multirow[t]{2}{*}{ Items } & \multicolumn{2}{|c|}{ Total sample } & \multicolumn{2}{|c|}{ Group 1} & \multicolumn{2}{|c|}{ Group 2} & \multirow[t]{2}{*}{$t$-cal } & \multirow[t]{2}{*}{ Sig. } \\
\hline & & Mean & Rank & Mean & Rank & Mean & Rank & & \\
\hline & \multicolumn{9}{|l|}{ Construction waste management requires } \\
\hline 67 & Applying source reduction through calculated procurement & 4.15 & 3 & 4.22 & 1 & 4.11 & 6 & 0.60 & 0.55 \\
\hline 68 & $\begin{array}{l}\text { Improving waste management onsite through metering / } \\
\text { measuring of resources }\end{array}$ & 4.04 & 7 & 4.07 & $2^{\mathrm{a}}$ & 4.02 & $7^{\mathrm{a}}$ & 0.25 & 0.81 \\
\hline 69 & Acquainting site workers to waste management strategies & 4.10 & 5 & 4.00 & 6 & 4.15 & 5 & -0.91 & 0.36 \\
\hline 70 & Sourcing materials off-site & 3.70 & 11 & 3.61 & 11 & 3.74 & 11 & -0.66 & 0.51 \\
\hline 71 & Ensuring timely delivery of materials, fittingly fabricated & 4.07 & 6 & 3.89 & 8 & 4.17 & 4 & -1.63 & 0.11 \\
\hline 72 & Avoiding $10 \%$ extra procurement in tendered document & 3.92 & 9 & 3.78 & 9 & 3.99 & 9 & -1.12 & 0.27 \\
\hline 73 & Negotiating for buy-backs of materials not used & 3.81 & 10 & 3.70 & 10 & 3.87 & 10 & -0.79 & 0.43 \\
\hline 74 & Using designed sections for mixing and concreting & 4.16 & 2 & 4.07 & $2^{\mathrm{a}}$ & 4.21 & 2 & -0.86 & 0.39 \\
\hline & \multicolumn{9}{|l|}{ Demolition waste management requires } \\
\hline 75 & Material auditing before deconstruction or demolition & 4.18 & 1 & 4.04 & 4 & 4.25 & 1 & -1.25 & 0.21 \\
\hline 76 & Onsite sorting of waste materials using designated areas & 4.13 & 4 & 4.02 & 5 & 4.18 & 3 & -1.00 & 0.32 \\
\hline 77 & $\begin{array}{l}\text { Reusing of would-be wastes onsite e.g. concrete masonry } \\
\text { unit wastes for filling }\end{array}$ & 3.99 & 8 & 3.91 & 7 & 4.02 & $7^{\mathrm{a}}$ & -0.53 & 0.59 \\
\hline & Cluster value & 4.02 & & 3.94 & & 4.06 & & -1.31 & 0.19 \\
\hline
\end{tabular}

Note: Group 1 refers to lecturers, instructors, teachers and technologists teaching building construction and related trades in tertiary and secondary institutions. Group 2 refers to building industry workers such as engineers, architects, technicians, plumbers, etc with minimum of Senior Secondary certificate in building related trades. ${ }^{a}=$ Equal ranks wherein the next rank is skipped; $t$-cal $=$ Calculated $t$-value; Sig. $=$ Level of significance at 0.05 .

clean environment (air, water and noise pollution) goal of GB [55] and equally vital in reducing building related illnesses [4]. On the other hand, the least ranked capacities needed for GB constructions are item 48, 'reusing onsite generated topsoil in landscaping' and item 51 'sourcing reclaimed materials for site equipment.' It is generally accepted by the respondents that there is no need for capacity building in neither managing topsoil nor in using reclaimed materials. Though it is observed across sites that topsoil are shed-off, compacted or destroyed by heavy traffic without consideration while new site equipment including site houses, seats and tables are made afresh in most sites instead of using reclaimed materials with the benefits of reducing waste, manufacturing time, energy consumption, thereby encouraging recycling $[4,42]$.

The result from $t$-test analysis in Table 3 shows that 4 of the 17 items were significantly different. The cluster $t$-value of 0.02 proves the significant difference in the responses of educational sector workers and building industry workers on GB construction needs, which further support the finding that discrepancies exist in theory and practice [48]. Therefore, the hypothesis that there is no significant difference in the mean response of building industry employees and educational sector employees on the GB construction needs was rejected.

\subsection{GB operation and maintenance needs}

From the results in Table 4, ranked first across the three categories is item 53 ' proper documentation of installations and input details.' According to Kubba [56] the need for

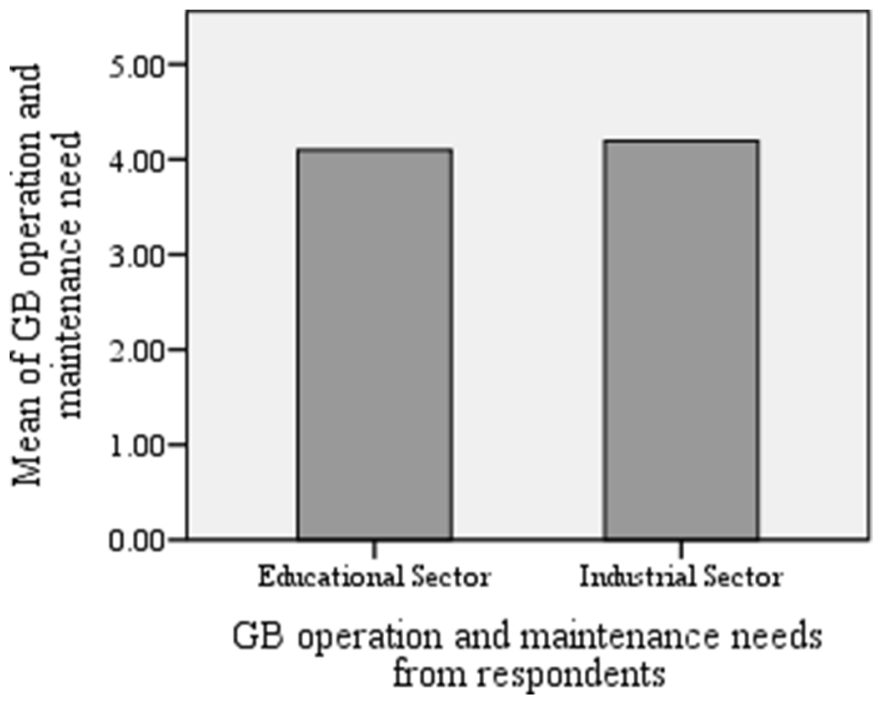

Fig. 4. GB operation and maintenance capacity building needs.

documentation in every stage of the construction is to enable efficient operation, maintenance or renovation of the building to meet future needs. In the same light, ranked second in total sample responses is item 59, 'training building occupants and stakeholders on operation and maintenance of features' on which Sinopoli [57] stated that every stakeholder including the security and facility managers require training for the management, operation and maintenance of the whole building system. Also 


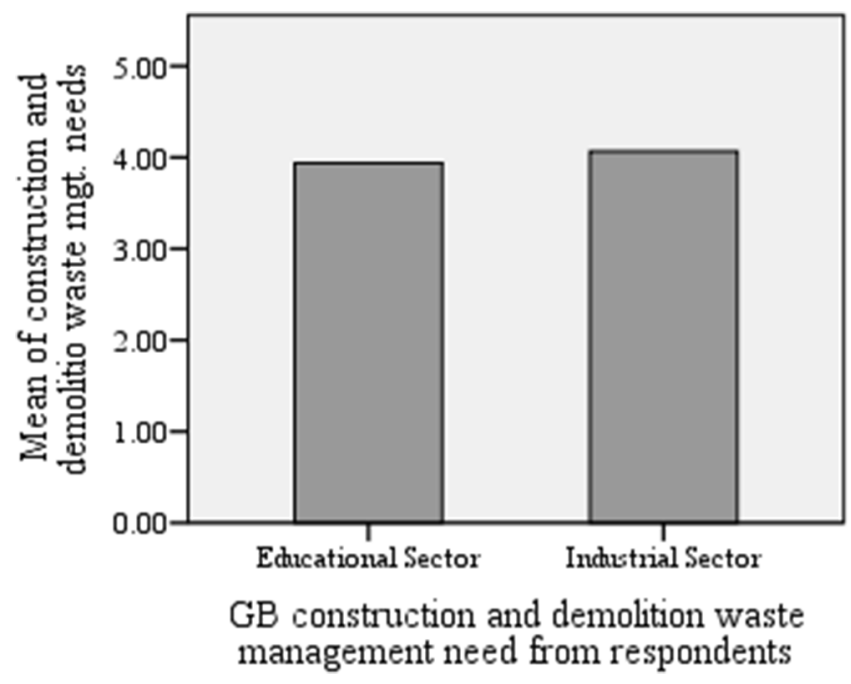

Fig. 5. GB construction and demolition wastes management capacity building needs.

substantiating the above outcomes are the third ranked item 55 'providing operational and maintenance manual of buildings' and fourth ranked item 60 'estimating schedules for repairs or replacement'. It follows thus that the place of documentation is key to operating and maintaining either refurbished or new GB [33]. In addition, maintenance manuals serve as guide and reminder for scheduled/ planned or preventive actions necessary to ensure safety, usability, lifetime quality of components and keep the building in 'steady state.' [36-38]. Furthermore, Table 4 shows the $t$-test analysis of the responses from the two groups, with the mean responses on GB operation and maintenance having no significant difference except for item 53. It is generally acceptable that the lifespan of GBs and return on investment depend on the level of care through repair and maintenance given to the buildings [33].

\subsection{GB construction and demolition waste management needs}

In Table 5, the first five of construction and demolition waste management needs according to the total sample are: item 75, 'material auditing before deconstruction or demolition', item 74 'using designed sections for mixing and concreting', item 67 'applying source reduction through calculated procurement', item 76 'onsite sorting of materials using designated areas' and item 69 'acquainting site workers to waste management strategies.' This finding is in line with Darko et al. [44] alongside other literatures, stating that reducing construction and demolition waste is one of the major drivers of GB, as such material auditing before deconstruction or demolition is vital in reducing the $30-40 \%$ solid waste produced by the construction industry [44,41]. More so, salvaged materials can be resold to offset construction and deconstruction costs [58-60]. Also, Dahlbo et al. [61] supported that source separation, auditing and onsite sorting of building materials will enable selection of reusable and recyclable components. According to Ma [42] it is possible to procure materials without additional $10 \%$ allotted to waste, hence the necessity and agreement to apply source reduction through calculated procurement.

Table 5 further reveals that the $t$-cal values of all the 11 items (67-77) were not significant at 0.05 level of significance. It shows that the cluster $t$-cal of -1.31 with $p$-value of 0.19 calculated at 0.05 level of significance, was greater than 0.05 and was not significant, therefore the hypothesis was not rejected. The unanimous agreement among respondents from educational and industrial sectors underscores the importance of CDW management towards GB development.

\section{Conclusion}

In response to the call for sustainability in the built environment, green constructions seek to address reduction in energy and material consumption, recycle and reuse materials to save environment, enhance economic development and improve quality of life for all. To ensure that developing countries align with the developed in adopting and advancing GB constructions, the study aimed at identifying the capacity building needs towards GB adoption. This is important as there is yet a wholesome $\mathrm{GB}$, in spite of observable green features [62] practiced alongside conventional constructions in Nigeria and in Enugu State. The main areas of capacity needs for adopting GB are clearly identified in this study.

The result from the statistical analysis of 135 returned questionnaire showed that there is need for capacity building in the five areas: GB design (total sample cluster mean $=4.14$ ), GB siting (total sample cluster mean= 4.04 ), GB construction (total sample cluster mean $=4.16$ ), GB operation and maintenance (total sample cluster mean $=4.16$ ), and GB construction and demolition waste management (total sample cluster mean $=4.02$ ). The following recommendations are made to facilitate the adoption of GB constructions in Enugu State:

- Campaigns, media houses, lectures, workshops and seminars should be engaged and organized to drive the GB knowledge beyond the publicity it currently has. Publicity can drive knowledge and set the stage for competitions and incentives to complying constructions. - Greenfield invasion should be discouraged. Already invaded brownfield, gray field and black field within cities should be assessed for upgrades, repairs, and redevelopment. Reusing and recycling lands have variant benefits.

- Trainings should be conducted for workers on new technologies and products. This is vital to ensure accurate installation of materials during construction thereby minimizing wastes.

- There is need for proper documentation of installations and input details from specialist in the various categories. Building operators can be educated on the whole building systems and maintenance requirements based on the documentations.

- During constructions, mixing and concreting should be in designated areas while offsite productions are encouraged. There is need for material auditing before any 
deconstruction is engaged and onsite sorting for reusing and recycling.

The major aim of this study was to open up the knowledge gap in conventional constructions, requiring additional trainings, seminars and workshops to aid GB adoption in Enugu State, Nigeria and other developing countries. It is observed that educational sector and industrial sector workers in building related fields agree reasonably in the aspects of GB examined (see Figs. 1-5). The figures show similarities in pattern of responses, indicating synergy on the importance of GB capacity building to both sectors. The capacity building needs in GB open up channel to follow towards synergizing theories in school and practical skills required in the world of work in this era of green constructions.

The practical implications of the empirical results are viable as the items with high mean ranking across total sample will guide decisions focused on up-skilling the educational and industrial sectors engaged in building constructions. Philanthropists and Sustainable Development advocates can leverage on this study to stir up grassroots green material developments through challenges and competitions in research and products. Also, government can rely on this study to create avenue for national reorientation towards GBs by organizing workshops with specialists from countries with robust sustainable construction practices such as Germany and China.

The researchers acknowledge the anonymous reviewers whose inputs made this write-up better. Also, acknowledgment goes to the respondents who took their time in completing the questionnaire upon which this article was developed.

\section{References}

1. Q.K. Qian, E.H.W. Chan, A.G. Khalid, Challenges in delivering green building projects: unearthing the transaction costs (TCs), Sustainability 7, 3615-3636 (2015)

2. D. Dahiru, A.A. Dania, A. Adejoh, An investigation into the prospects of green building practice in Nigeria, J. Sustain. Dev. 7, 158-167 (2014)

3. A. Darko, A.P.C. Chan, Strategies to promote green building technologies adoption in developing countries: the case of Ghana, Build. Environ. 130, 74-84 (2018)

4. C.J. Kibert, Sustainable construction: green building design and delivery (John Wiley \& Son Inc., New Jersey, 2013)

5. United Nations, Earth Summit: UN conference on environment and development. Retrieved from: www.un.org/ geninfo/bp/enviro.html Accessed: August 4, 2017

6. D.R. Riley, C.E. Thatcher, E.A. Workman, Developing and applying green building technology in an indigenous community: an engaged approach to sustainability education, Int. J. Sustain. Higher Edu. 7, 142-157 (2006)

7. I. Nwokoro, H. Onukwube, Sustainable or green construction in Lagos, Nigeria: principles, attributes and framework, J. Sustain. Dev. 4, 166-174 (2011)

8. A.J. Hoffman, R. Henn, Overcoming the social and psychological barriers to green building. Organ. Environ. 21, 390-419 (2008)
9. B.P. Ogunsote, O.O. Ogunsote, O.A. Ude, V.B. Ogunsote, Towards the establishment of a green building council and the development of a green building rating system for Nigeria (2016). Retrieved from: https//www.researchgate.net/publi cation/267784294 accessed: November 12, 2018

10. B.N. Okafor, Green building for Nigeria public institutions towards effective administrations of public properties: a case study of military barracks and police stations in Anambra state, Nigeria, Int. J. Phys. Human Geogr. 4, 16-22 (2016)

11. National Population Commission (NPC), Sentinel survey of the national population programme baseline report, 2000 (NPC, Abuja, 2002)

12. L. Njoku, 'Enugu moves to provide affordable housing', The Guardian, Nigeria, 26 August 2018. Available at: https:// guardian.ng/news/enugu-moves-to-provide-affordable-hous ing/ (Accessed: 5 February 2019)

13. Agency Reporter, 'Enugu govt develops six housing estate in one year', The Nation - Nigeria, November 12, 2017. Available at: http://thenationonlineng.net/enugugovt-develops-six-housing-estates-in-one-year/ (Accessed: 5 February 2019).

14. A.P.C. Chan, A. Darko, E.E. Ameyaw, D. Owusu-Manu, Barriers affecting the adoption of green building technologies, J. Manag. Eng. (2016). https://doi.org/10.1061/(ASCE) ME.1943-5479.0000507

15. L. Brown, A. LaFond, K. Macintyre, Measuring capacity building (University of North Carolina, North Carolina, 2001)

16. United Nations Development Programme, Capacity building: a UNDP primer. New York: United Nations Development Programme (2009). Retrieved from: www.undp. org > capacity-building

17. L. Pintér, G.A. Huppé, Capacity-Building Courses for Integrating Sustainable Development into Policy Planning and Implementation, Sustain. Technolog. Build. Constr. Ind. (2014) Available at: www.sdplannet.org (Accessed: 5 February, 2019)

18. C. Potter, R. Brough, Systemic capacity building: a hierarchy of needs, Health Policy Plan 19, 336-345 (2004)

19. H. Virji, J. Padgham, C. Seipt, Capacity building to support knowledge systems for resilient development-approaches, actions, and needs, Curr. Opin. Environ. Sustain. 4, 115-121 (2012)

20. Balramdas, P. Meher, S. Behera, B. Rath, S. Dash, P. Choudhary, A comparison between Normal buildings and Green buildings: a case study approach, Int. Res. J. Eng. Technol. 3, 2372-2395 (2016)

21. N. Kohler, The relevance of green building challenge: an observer's perspective, Build. Res. Inf. 27, 309-320 (1999)

22. M. Ristimäki, A. Säynäjoki, J. Heinonen, S. Junnila, Combining life cycle costing and life cycle assessment for an analysis of a new residential district energy system design, Energy 63, 168-179 (2013)

23. R. Plank, The principles of sustainable construction, IES J. Part A: Civil Struct. Eng. 1, 301-307 (2008)

24. Los Alamos National Laboratory, Sustainable Design Report for Los Alamos National Laboratory's Strategic Computing Complex (2001). Accessed 27th December, 2017

25. Sustainable Sources, Site selection and analysis (n.d.). Retrieved from: sustainablesources.com/site-selection-andanalysis/ Accessed: June 4, 2018 
26. C. Du Plessis, A strategic framework for sustainable construction in developing countries, Constr. Manag. Econ. 25, 67-76 (2007)

27. NJ Green Building Manual, Green building techniques (2011). Retrieved from: registry.njsbdc.com/resources/ green-building-techniques Accessed: June 16, 2018

28. National Institute of Building Sciences, Optimize operational and maintenance practices. WBDG Sustainable Committee (2018). Retrieved from: https://www.ubdg.org/design-objec tives/sustainable/optimize-operational-maintenance-practices Accessed. July 10, 2018

29. L. Brenner, List of Endangered Animals of the Desert. Sciencing (2018). Retrieved from: https://sciencing.com/ list-of-endangered-animals-desert-7299045.html

30. National Oceanic and Atmospheric Administration, What is the difference between a threatened and endangered species? (2018) Retrieved from: https://oceanservice.noaa.gov/facts/ endangered.html. Accessed: June 14, 2018

31. Environment Protection Agency, Green Building (2018). From: http://www.epa.gov/greenbuilding/pubs/about. htm. December 18, 2018

32. R.S. Sumit Sharma, Indoor air quality: issues and concerns in India (2014). Retrieved from: www.grihaindia.org/events/ tgs2014/pdf/Sumit-Sharma.pdf\&ved=2ahUKEwj Accessed: June 14, 2018.

33. M. Riley, A. Cotgrave, Technology of refurbishment and maintenance, Struct. Surv. 22 (2004). https://doi.org/10.1108/ ss.2004.11022eae.007

34. European Federation of National Maintenance Societies, Maintenance (2016) Retrieved from: www.efnms.eu. Accessed: August 5, 2016

35. Defence Logistics Agency, Maintenance (2016). Retrieved from: www.dla.mil Accessed: August 5, 2016.

36. B. Chanter, P. Swallow, Building maintenance management (2008), Wiley Online Library. https://doi.org/10.1002/ 9780470692011

37. M.A. Oliveira, I.S. Lopes, D.L. Figueiredo, Maintenance management practices of companies of the industrial pole of Manaus, Proc. World Congr. Eng. Comput. Sci. 2, 22-24 (2014)

38. M.J. Thaheem, A. De Macro, Sustainable Repair \& Maintenance of buildings in the developing countries: a risk management perspective and proposal of customized framework, J. Civil Eng. Arch. Res. 1, 14-23 (2014)

39. N. Aghili, A.H.B. Mohammed, L. Sheau-Ting, Key practice for green building management in Malaysia, MATEC Web Conf. 66, 5 (2016)

40. M.R. Merino, P.I. Gracia, I.S.W. Azevedo, Sustainable construction: construction and demolition waste reconsidered, Waste Manag. Res. 28, 118-129 (2010)

41. European Commission, Construction and demolition wastes (2017). Retrieved from: ec.europa.eu/environment/waste/ construction_demolition.html February 22, 2018

42. U. Ma, No waste: managing sustainability in construction (Gower Publishing Ltd., UK, 2011)

43. M.D. Gall, J.P. Gall, W.R. Borg, Educational Research: an introduction, 8th edn. (Pearson, Utah, 2007)

44. A. Darko, A.P.C. Chan, D. Owusu-Manu, E.E. Ameyaw, Drivers for implementing green building technologies: an international survey of experts, J. Clean. Prod. (2017). http://dx.doi.org/10.1016/j.jclepro.2017.01.043
45. D.O. Nduka, A.S. Sotunbo, Stakeholders perception on the awareness of green building rating system and accruable benefits in construction projects in Nigeria, J. Sustain. Dev. Africa 16, 118-130 (2014)

46. T.H. Jasmine, H.M. Ali, Valuation of green commercial office building: a preliminary study of Malaysian Valuers' insight, Int. Schol. Sci. Res. Innov. 9, 2879-2884 (2015)

47. G.O. Deniz, An analytic network process (ANP) model to examine LEED-certified buildings operational performance, Built Environ. Project Asset Manag. 7, 366-376 (2017)

48. H. Spork, Environmental education: a mismatch between theory and practice, Aust. J. Environ. Edu. 8, 147-166 (1992)

49. EPA, Contaminated site management (2017). https://www. epa.vic.gov.au/your-environment/land-and-groundwater/ contaminated. Retrieved: February 18, 2018

50. P. Newman, J. Kenworthy, Sustainability and Cities: Overcoming Automobile Technologies, Examples (Island Press, Washington, 1999)

51. N.A. Al-Hajeri, Green Building and Energy Saving. World Academy of Science, Engineering and Technology International Journal of Humanities and Social Sciences, Int. Schol. Sci. Res. Innov. 7, 2285-2291 (2013)

52. M.S. Hasan, R. Zhang, Critical Barriers and Challenges in Implementation of Green Construction in China, Int. J. Curr. Eng. Technol. 6, 435-445 (2016)

53. F.P. Rahimian, J. Goulding, A. Akintoye, S. Kolo, Review of Motivations, Success Factors, and Barriers to the Adoption of Offsite Manufacturing in Nigeria, Proc. Eng. 196, 512-519 (2017)

54. B.G. Hwang, J.S. Tan, Sustainable project management for green construction: challenges, impact, and solutions, World Construction Conference 2012-Global Challenges in Construction Industry 28-30 June 2012, Colombo, Sri Lanka (2012). Retrieved from https://www.irbnet.de/daten/ iconda/CIB_DC25123.pdf. Accessed June 26, 2019

55. J. Gary, Pollution from construction (2018). www.sustaina blebuild.co.uk/pollutionfromconstruction.html Retrieved: December 18, 2018

56. S. Kubba, Green project commissioning, in Handbook of Green Building Design and Construction, 2nd edn. (2017)

57. J. Sinopoli, Design, construction, and renovations. In Smart Building Systems for Architects, Owners and Builders (2010). https://doi.org/10.1016/B978-1-85617-6538.00013-2

58. N. Calvo, L. Varela-Candamio, I. Novo-Corti, A dynamic model for construction and demolition (C\&D) waste management in spain: driving policies based on economic incentives and tax penalties, Sustainability 6, 416-435 (2014)

59. C. Jeffery, Construction and Demolition Waste Recycling A Literature Review. Dalhousie University's Office of Sustainability (2011). Retrieved from https://cdn.dal.ca/content/ dam/dalhousie/pdf/dept/sustainability/Final\%20C\%26D\% 20literature\%20review.pdf Accessed June 26, 2019

60. Northwest Economic Research Center, The Economics of Residential Building Deconstruction in Portland. Portland State University (2016). Retrieved from https://www.pdx. edu/nerc/sites/www.pdx.edu.nerc/files/BPS\%20NERC\% 20Deconstruction\%20Study\%20Final\%20Report\%205-7_0. pdf Accessed June 26, 2019 
61. H. Dahlbo, J. Bacher, K. Leahtinen, T. Jouttijaarvi, P. Souheimo, T. Mattila, S. Sironen, T. Myllymaa, K. Sarameaki, Construction and demolition waste management - a holistic evaluation of environmental performance, J. Clean. Prod. 107, 333-341 (2015)
62. S.G. Dalibi, J.C. Feng, L. Shuangqin, A. Sadiq, B.S. Bello, I.I. Danja, Hindrances to green building development in Nigeria's built environment: the project professionals' perspectives", IOP Conf. Ser. 63 (2017). https://doi.org/ $10.1088 / 1755-1315 / 63 / 1 / 012033$

Cite this article as: D.U. Chukwu, E.A. Anaele, H.O. Omeje and I.B. Ohanu: Adopting green building constructions in developing countries through capacity building strategy: survey of Enugu State, Nigeria. Sust. Build. 4, 4 (2019). 